\title{
高じん性アルミナのき裂面架橋に及ぼす負荷応力拡大係数の影響
}

\section{Effect of Applied Stress Intensity Factor on Crack Face Bridging in Toughened Alumina}

\author{
○学 成田 康一郎（静大院） 正 坂井田 喜久（静大工）
}

Koichiro NARITA and Yoshihisa SAKAIDA, Shizuoka University, 3-5-1 Johoku Naka-ku, Hamamatsu 432-8561, Japan

Key Words: Toughened Alumina, Crack Face Bridging, Stress Intensity Factor, Fracture Toughness

\section{1. 緒言}

近年，セラミックスの微構造を積極的に制御することによ って高じん化を達成する材料プロセスが開発 ${ }^{12)}$ されている. 特にアルミナのような粒界破壊が支配的な材料は，き裂面の 粒子架橋によって高じん化を達成している．本研究は，通常 アルミナの約 2 倍のじん性值を持つ高じん性アルミナに注目 し, き裂開口変位の測定とき裂モデルの有限要素法解析によ って, き裂面架橋が架橋力分布や高じん化に及ぼす影響につ いて検討した.

\section{2. 実験および解析方法}

2.1 供試材及び試験片 供試材は，ホットプレス焼結アル ミナ（以下 TAL，産総研製）で，表 1 に主な機械的性質を示 す．実験には幅 $3 \mathrm{~mm} \times$ 厚さ $4 \mathrm{~mm} \times$ 長さ $40 \mathrm{~mm}$ の短冊試験片中 央に Pop-in き裂を導入した片側き裂試験片を用いた。なお, 試験片のき裂先端には図 1 に示寸直交座標系 $x y z$ を定義した.

Table.1 Mechanical properties and initial crack lengths of sample.

\begin{tabular}{l|l}
\hline \hline Young's modulus $E(\mathrm{MPa})$ & 384 \\
Poisson's ratio & 0.24 \\
Fracture toughness $K_{I C}\left(\mathrm{MPam}{ }^{0.5}\right)$ & 8.0 \\
Bending strength $\sigma_{B}(\mathrm{MPa})$ & 400 \\
Crack length of side- $1(\mathrm{~mm})$ & 1.72 \\
\multicolumn{1}{c|}{ side-2 $(\mathrm{mm})$} & 1.83 \\
\hline
\end{tabular}

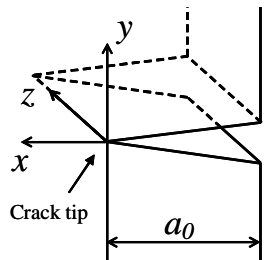

Fig.1 Definition of coordinate system.
2.2 き裂側面の開口変位測定 片側き裂試験片に表 2 に示 すような一定の曲げモーメントを負荷して走査型電子顕微 鏡（日本電子製）内に挿入し，き裂側面の開口状態を写真撮 影した。 き裂開口変位 $\delta_{E X P}(x)$ は，き裂先端から $5 \mu \mathrm{m}$ 間隔で SEM 写真から計測し, $25 \mu \mathrm{m}$ 毎の平均值で整理した.

片側き裂試験片の負荷応力拡大係数 $K_{a p p}$ は,

$$
K_{a p p}=\frac{3 P\left(S_{1}-S_{2}\right)}{2 B W^{2}} F(\alpha) \sqrt{\pi a}
$$

より求めた ${ }^{3)}$. 上式で, $P$ は四点曲げ荷重, $S_{1}$ は外スパンで $36 \mathrm{~mm}, S_{2}$ は内スパンで $20 \mathrm{~mm}, B$ は試験片幅, $W$ は試験片厚 さである. なお, $F(\alpha)$ は次式より求まる形状係数である ${ }^{4)}$.

$$
F(\alpha)=\sqrt{\frac{2}{\pi \alpha} \tan \left(\frac{\pi \alpha}{2}\right)} \frac{0.923+0.199\left(1-\sin \left(\frac{\pi \alpha}{2}\right)\right)^{4}}{\cos \left(\frac{\pi \alpha}{2}\right)}
$$

Table.2 Loading conditions for in-situ measuring COD.

\begin{tabular}{l|c|c|c|c}
\hline \hline & 1 & 2 & 3 & 4 \\
\hline$K_{a p p} / K_{I C}(\%)$ & 60 & 65 & 55 & 70 \\
$K_{a p p}\left(\mathrm{MPam}^{0.5}\right)$ & 4.8 & 5.2 & 4.4 & 5.6 \\
Applied load $P(\mathrm{~N})$ & 102 & 111 & 94 & 119 \\
\hline
\end{tabular}

2.3 き裂モデルの作成と 3 次元有限要素法解析 図 2 に示 すような片側き裂試験片の $1 / 2$ モデルを有限要素法上に作成 し, き裂開口変位の実測值と比較しながら架橋力分布やき裂
面架橋による応力遮へい効果を破壊力学的に見積もった ${ }^{5) 6)}$. 詳細は次章で述べる.解析には, 市販ソフトANSYS を用い, き裂モデルは，実験に用いた片側き裂試験片と同一形状，同 一き裂長さに設定した。

\section{3. 結果及び考察}

3.1 き裂開口変位の測定結果 図 3 は, 負荷条件 1 にて, SEM 観察により実測したき裂開口変位分布 $\delta_{E X P}(x)$ と，き裂 面に相互作用のない場合に FEM 解析により求めた $\delta_{0}(x)$ を示 す. 図より, $\delta_{E X P}(x)$ は, $\delta_{0}(x)$ に比べて明らかに開きが少なく, TAL のき裂面に, $K_{a p p}$ に対してき裂先端の引張応力を遮へい する相互作用が働いていることがわかる.

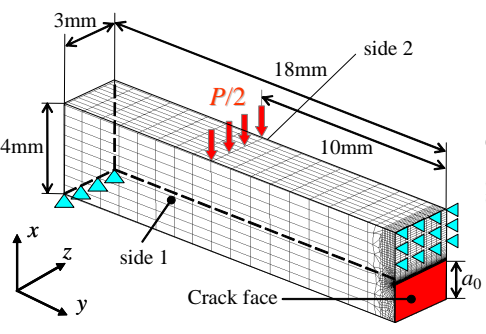

Fig.2 Finite element model of SEPB specimen.

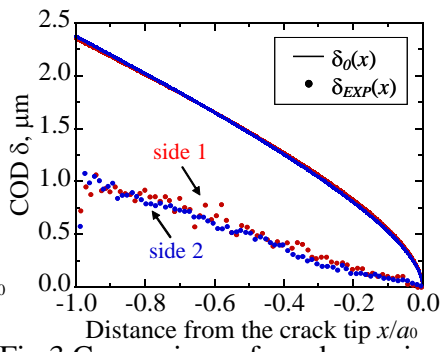

Fig.3 Comparison of crack opening displacements, $\delta_{E X P}(x)$ and $\delta_{0}(x)$.
3.2 き裂開口変位と応力拡大係数の関係 き裂先端近傍の 開口変位 $\delta_{t i p}(x)$ とき裂先端の応力拡大係数 $K_{t i p}$ の関係は, 線形 破壊力学より次式で表わされる ${ }^{4)}$.

$$
K_{\text {tip }}=E \delta_{\text {tip }}(x) \sqrt{2 \pi /|x|} / 8
$$

ここで，き裂面に相互作用のないき裂モデルに $P=100 \mathrm{~N}$ $\left(K_{\text {app }}\right.$ に換算すると $\left.4.7 \mathrm{MPam}^{0.5}\right)$ 負荷したときのき裂開口変位 $\delta(x)$ を FEM 解析より求めて上式に代入すると, 図 4(a)に示す ように $K_{a p p}$ と一致しない。 そこで，片側き裂試験片の開口変 位 $\delta(x)$ から計算される $K_{\text {tip }}$ が $K_{\text {app }}$ と一致するような補正式を FEM 解析より求め ${ }^{6)}$, 次節の $K_{\text {tip }}$ の算出に用いた.

$$
K_{\text {tip }}=C(x) E \delta(x) \sqrt{2 \pi /|x|} / 8
$$

ここで, $C(x)$ は補正係数で, 図 4(a)より $0<|x| / a_{0}<0.2$ は 5 次, $|x| / a_{0}>0.2$ は 2 次の多項式で近似した. 図 4(b)は, 式(4)より計 算した $K_{t i p}$ を示す. 図より，き裂全域の開口変位に対し， $K_{t i p}$ が算出できることがわかる.

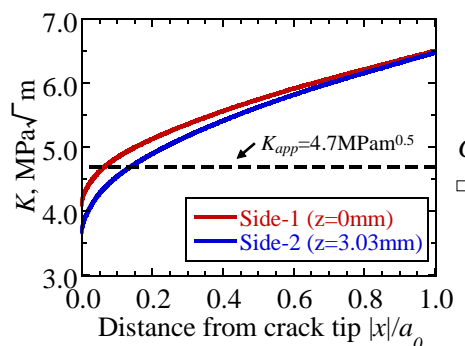

(a) $K_{\text {tip }}$ calculated by eq. (3)

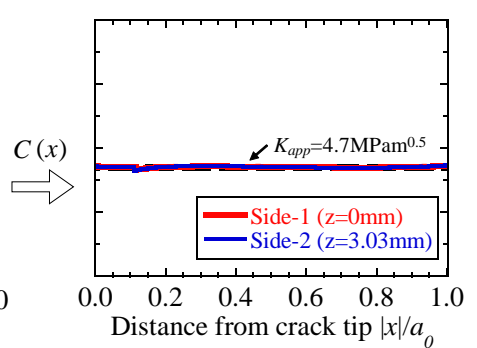

(b) $K_{\text {tip }}$ calculated by eq. (4)
Fig.4 Comparison of $K_{\text {tip }}$ with $K_{\text {app }}$ in FEM analysis. 
3.2 き裂先端の応力拡大係数 $K_{t i p}$ の算出 図 3 より, Pop-in き裂は，き裂面の相互作用によって開口量は狭くなり，き裂 先端の応力拡大係数 $K_{\text {tip }}$ は $K_{\text {app }}$ より 小さい.

図 5 は, 図 3 のき裂開口変位の実測值を式(4)に代入し,き 裂先端から距離に対して $K_{t i p}$ の累積平均を計算した結果を示 す。実際のき裂では，き裂面の架橋によって， $|x| / a_{0}>0.2$ で $K_{\text {tip }}$ の累積平均が一定值から次第に単調増加する傾向がある ことがわかる．本研究では，き裂先端近傍の一定值を図より 求め, Pop-in き裂試験片の $K_{\text {tip }}$ とした。 ここで, き裂面の相 互作用, すなわちき裂面の架橋力による応力拡大係数を $K_{b r}$ とすると, $K_{b r}$ は, $K_{b r}=K_{t i p}-K_{a p p}$ となる ${ }^{4)}$. よって, 図 5 よ り求めた $K_{t i p}$ から $K_{b r}$ が計算できる.

表 5 は, 表 2 の 4 条件で $P$ を負荷したときの開口変位から 求めた $K_{t i p}$ と $K_{b r}$ をそれぞれ示す. $K_{b r}$ 值は $K_{a p p}$ の約 73〜 87\% と高く, $K_{a p p}$ に対する応力遮へい効果が非常に高いことがわ かる.

一方, 図 6 は, $K_{a p p}$ に対する $K_{b r} / K_{a p p}$ の変化を示す. $K_{b r} / K_{a p p}$ 值は $K_{a p p}$ の増加とともに低下寸る傾向があることがわかる. すなわち, $K_{a p p}$ が増加すると, 後述するように, 架橋力は一 部増加するが, 開口量の増加によってき裂面の架橋が一部外 れることを示している.

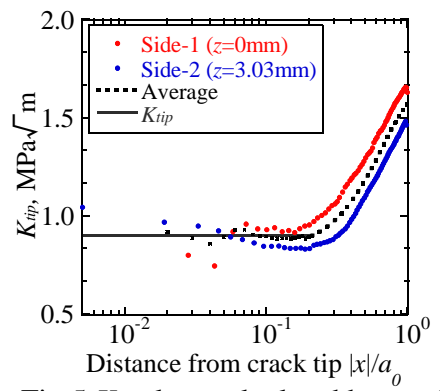

Fig. $5 \mathrm{~K}$-values calculated by eq. (4)

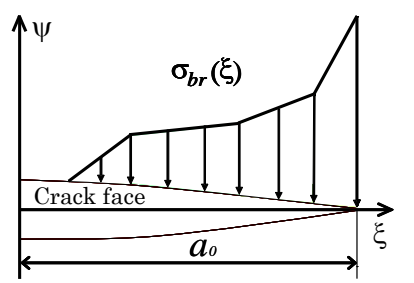

Fig.7 Definition of bridging stress distribution, $\sigma_{b r}(x)$.

3.3 架橋応分布 $\sigma_{b r}(x)$ の推定 き裂側面の SEM 観察結果や, き裂先端の応力拡大係数の算出から, き裂面には粒子架橋に よる架橋力が発生していることは明らかである。そこで，図 7 に示すような架橋力分布 $\sigma_{b r}(\xi)$ を仮定すると, き裂面の架橋 力による応力拡大係数 $K_{b r}$ は次式より破壊力学的に計算 ${ }^{4)}$ で きる。

$$
K_{b r}=\frac{2 F(\alpha)}{\sqrt{\pi a}} \int_{0}^{a} \sigma_{b r}(\xi) \sqrt{\frac{a+\xi}{a-\xi}} d \xi
$$

本研究では, 図 7 の架橋力分布 $\sigma_{b r}(\xi)$ を任意に変化させ, 式(5) で計算される $K_{b r}$ と表 5 の実験結果が一致する架橋力分布を 求めた（推定手順 1 ). 次に, 求めた架橋力分布をき裂モデ ルのき裂面に荷重条件として与え, 四点曲げ荷重 $P$ を負荷し たときのき裂開口変位 $\delta_{F E M}(x)$ を FEM 解析より求め, 図 3 の ような開口変位の実測值 $\delta_{E X P}(x)$ と比較し, 式(6)よりき裂全域 の 2 乗偏差の平均值 $\mu$ を求めた (推定手順 2). 推定手順 1 と 2 を繰返し, 平均值 $\mu$ が最小值を示すときの架橋力分布 $\sigma_{b r}(x)$ を最適值とした。

$$
\mu=\sqrt{\frac{1}{n} \sum_{i=1}^{n}\left(\delta_{F E M}(x)-\delta_{E X P}(x)\right)_{i}^{2}}
$$
較を示す. 式(6)より得た $\mu$ は $0.058 \mu \mathrm{m}$ と十分に小さく, 両者 はよく一致しているといえる。これより，き裂面に架橋力を 与えることによって開口量の変化を FEM 解析で予測できる ことがわかる。
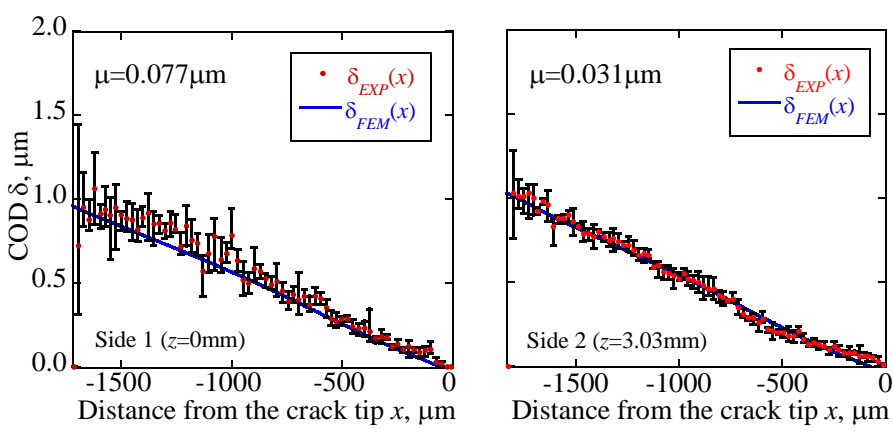

Fig.8 Crack opening displacements, $\delta_{\text {FEM }}(x), \delta_{\text {EXP }}(x)$.

図 9 は, 表 2 の 4 条件 における架橋力分布の最 適值を，それぞれ比較し た。図より,き裂先端か らき裂端にわたるき裂面 の全域に架橋力が分布し, その最大值はき裂先端に 発生することがわかった. また， $K_{I C}$ に対する $K_{\text {app }}$ が 55\%から 60\%に増 加寸ると, き裂端の広い 領域で架橋応力が増加す る傾向がみられた.一方, 60 から 65\%では, 開口量 の増加によってき裂面の 架橋がき裂端から次第に 外れ, き裂端に近い領域 の架橋力は低下寸るが, き裂先端の架橋力が増加 して再分布した. 続けて 70\%へと増加させると， き裂端よりも前方の領域 でも架橋が外れ, き裂先 端近傍の架橋力がさらに 増加する傾向があること がわかった。

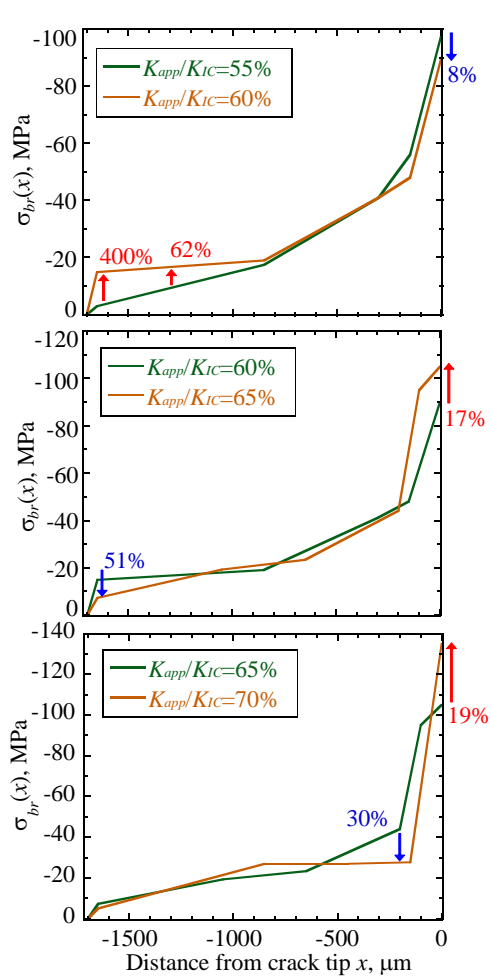

Fig.9 Bridging stress distributions estimated by FEM analysis.
図 8 は負荷条件 1 の開口変位の FEM 解析值と実験值の比

\section{5. 結言 省略}

\section{参考文献}

1）シナジーセラミックス研究体編 “機能共生の指針と材 料創成”, p.3 (2000), 技報堂出版.

2) 平野眞一, 新原皓一, 島田晶彦, 神埼修三, 拓殖章彦, 工業と製品, vol.27,34 (1999).

3) Y. Murakami et al. Stress Intensity Factors Handbook vol.1, Pergamon Press, p.16 (1987).

4) 岡村弘之, 破壊力学と材料強度講座 線形破壊力学入 門, p.22, p.40, p.213, p.218 (1980), 倍風館.

5) 森祥太郎, 坂井田喜久, 日本材料学会第 43 回 X 線材料強 度に関するシンポジウム講演論文集, pp.86-91 (2008).

6) 成田康一郎, 坂井田喜久, 日本材料学会第 45 回 X 線材料 強度に関するシンポジウム講演論文集, pp.61-66 (2011). 